\title{
1 An introduction to COVID-19 and federalism
}

\author{
Rupak Chattopadhyay, Felix Knüpling and \\ Liam Whittington
}

The COVID-19 pandemic is an unprecedented international event. The spread of the coronavirus - the biggest public health crisis in a century and the first of this scale in the globalized modern world - has prompted unparalleled responses by national governments. The proliferation of 24-hour news coverage and social media has allowed people across the world to follow, in real time, the unfolding and visible impacts of the pandemic.

This book is about the impact of the crisis on federal and multilevel systems, which account for approximately 40 percent of the world population. ${ }^{1}$ In 2020 , as governments grappled with fluctuating waves of the COVID-19 pandemic, the effectiveness of public policy varied among federal nations. Federal countries such as Australia and Canada managed to keep mortality low, whereas others such as Brazil, Spain, and the United States suffered some of the highest numbers of fatalities anywhere around the world, both in absolute and relative terms (Brunner et al. 2020; Ionova 2020; Kontis et al. 2020, pp. 1919-1928; Ritchie et al. 2021).

A 2015 Forum of Federations workshop on "Emergency Management in Federal Countries," which brought together emergency management professionals from half a dozen nations, did not even consider the question of transnational pandemics (Forum of Federations 2015). Focusing primarily on natural disasters such as fires, earthquakes, floods, and climate adaptation, the subsequent report reflected the recurring issues that routinely demand the attention of emergency management departments in all countries. Perhaps because recent pandemics such as SARS-CoV and H1N1 had a relatively limited geographic footprint, the COVID-19 tsunami took policy makers everywhere by surprise (Relman, Chofness and Mack 2010; World Health Organization 2003). The novelty of the virus, and a lack of information on its origin and effects in the early phases of the outbreak, enabled it to spread unchecked for several months before controls were subsequently introduced (World Health Organization 2020; Wu et al. 2020).

While, in most federal countries, the constitutional power to deal with national disasters or emergencies resides with the federal government, the delivery of health services is often the remit of constituent units, such as states, provinces, and cantons, as well as local governments. ${ }^{2}$ Thus, responding to the public health and economic crisis brought on by the pandemic has required policy interventions at the level of federal governments as well as constituent units (OECD 2020). This has necessitated unprecedented levels of intergovernmental interaction and coordination between all orders ${ }^{3}$ in a federation. 


\section{Rupak Chattopadhyay et al.}

The pandemic has clearly raised questions about the effectiveness of the governance response to the crisis in federal (and devolved) countries. This touches on issues such as the roles and responsibilities of various orders of government and the adequacy of existing institutions and processes of intergovernmental relations. Furthermore, whether the pandemic has led to innovations in the practice of federalism, and thus whether federal countries now are better prepared to handle future pandemics, is a topic of substantial importance.

Following Oates' (1999) notion of "laboratory federalism," innovation in public policy through experimentation and mutual learning can be considered as one of the important advantages of federal systems. Accordingly, federal countries may be uniquely suited to grappling with the complexity and uncertainty of emergencies such as pandemics (Ferejohn, Eskridge and Bednar 2001; Greer et al. 2020). Federal models, so the theory purports, provide policy makers with opportunities to develop solutions tailored to different scales and circumstances, experiment with innovative policy measures, and engender policy learning and convergence over time. Conversely, political scientists argue that regulatory overlaps and coordination deficits are inherent in many federal systems, which may hinder the pursuit of effective responses to an emergency such as the COVID pandemic (ibid.).

The complex mosaic of actions adopted within many federal and multilevel systems prompts this comparative publication toward enhancing understanding on how different institutional frameworks, governance mechanisms, and political dynamics interact to shape emergency response. Of particular interest is the extent of cooperation between different orders of government, as well as effective and ineffective practice in pandemic management in federal and multilevel systems.

This volume provides a comparative overview of the policy response of $23 \mathrm{fed}$ eral or federal-type countries, and one supra-national organization, to the pandemic: Australia, Austria, Argentina, Belgium, Bosnia and Herzegovina, Brazil, Canada, Ethiopia, Germany, India, Italy, Kenya, Malaysia, Mexico, Nepal, Nigeria, Pakistan, Russia, South Africa, Spain, Switzerland, the United Kingdom, the United States, and the European Union. By federalism, we understand a system of governance which has at least two orders of government (one for the whole country and one for the constituent units) whose spheres of decision-making authority are protected constitutionally ${ }^{4}$ (Anderson 2008).

We recognize that the case studies covered in this volume include countries which do not strictly fall under the category of federalism. This includes the devolved multinational United Kingdom, Italy, which alongside to its federal features also exhibits strong elements of a unitary system of governance, and the supra-national case study of the European Union. Case studies of countries which do not refer to themselves as federal, such as Spain and South Africa, are also included.

The cases cover the majority of federal or federal-type countries from both the Global North and the Global South, with great institutional variation, differing levels of economic development, and diverse demographic profiles. While we acknowledge the challenges of comparative analysis of 24 very different case studies, we believe that there is significant value in this endeavor. Despite the uniqueness of each case and the many differences between the nations analyzed - in terms of their history, constitutional and institutional structures, and political and economic development - they do have common features and face the challenge of coordination and collaboration (Hueglin and Fenna 2015). 
The issue of coordination and collaboration between orders of government also guides our categorization of case studies. Comparing the response to the pandemic from a governance perspective, we identify three categories:

- National Government Dominated Responses;

- Strong Collaboration and Coordination between Jurisdictions;

- Weak Collaboration between Jurisdictions.

The categorization of the case studies is elaborated in greater detail in the comparative chapter, accompanied by identification of key trends across the countries analyzed.

At the time of writing in early 2021, globally the COVID-19 crisis is still very much ongoing and unlikely to abate in the short term. This volume focuses on examining the response to (as well as the impact of) the pandemic in the year 2020. During this period, many countries around the world experienced multiple waves of COVID-19 infections, some more or less severe than others. It is important to note that the phrase "first wave" (or indeed second or third wave) does not refer to a universal period of time globally. This is because COVID-19 peaked at different points in time in different countries. For example, the first wave peaked in Germany in late March 2020, in Canada in April 2020, and in India only in October 2020 (Ritchie et al. 2020). The country case studies therefore focus on the impacts of COVID-19 as the pandemic ebbed and flowed in the respective country over the course of 2020.

The chapters in this book consider how the pandemic has tested not just systems of government but also the robustness of existing governing arrangements in a range of areas. In many federations, emergency management is a federal responsibility, and the federal government tends to have some regulatory or oversight power over health care systems. However, the delivery of health care services is typically either a constituent unit or concurrent responsibility (Marchildon and Bossert 2018). Given the clustering of infection in urban areas, local governments have become essential components of the COVID-19 management strategy, particularly in delivering sanitation services, managing public spaces, and enforcing quarantine/lockdown restrictions (OECD 2020). Consequently, effective pandemic management has required closer coordination between the various orders of government.

In this volume, chapter authors will help readers understand the institutional and policy context in which countries have responded to COVID-19, and how these conditions shaped the response. The political scientists, serving government officials, and senior governance practitioners who comprise the authors of this book bring a wealth of academic and practical experience to their analysis. We believe, therefore, that the case studies will be of value to both researchers and governance practitioners, as well as anyone with an interest in the field of emergency management.

In the first section of each chapter, authors provide an analysis of how the institutional architecture of each country shaped their responses to the health and economic crisis brought on by the pandemic. They consider how effective intergovernmental coordination has been in each country and whether existing intergovernmental institutions and processes were fit for purpose. The extent to which constituent unit governments were able to effectively deliver health care services is also assessed.

In the second section, the analysis focuses on lessons learnt as a consequence of the first year of the pandemic. Many countries emerged from 2020 having suffered at least one wave of infections, and face the challenge of "living with the virus" as well 


\section{Rupak Chattopadhyay et al.}

as tackling subsequent resurgences in cases. During peaks in cases, governments have, in a context of great uncertainty, been forced to make unenviable decisions to protect the lives of citizens. The unprecedented imposition of lockdowns, school closures, and stay at home orders as a last resort underscores the challenge of balancing the health dimension of the pandemic with the potentially severe economic, social, and psychological consequences of the pandemic response. The effects of both COVID-19 and the policies employed to control it will most likely keep governments occupied for years to come. Are there lessons learnt to date that can produce improvements in how governments deal with future outbreaks?

Finally, each chapter offers reflections on how COVID-19 is likely to transform the nature of the federation (or governance system in federal-type nations). Does the pandemic change everything or nothing? Or only some things? The questions of economic recovery, the precariousness of constituent unit finances, and the importance of the graduated bespoke responses that constituent unit governments can provide are particularly germane to our understanding of how federal relations are rebalanced in post COVID-19 world.

\section{Notes}

1 The analysis focuses on countries that are explicitly and constitutionally federal, and countries with governance systems in which governance powers and responsibilities are devolved from the central level to the subnational level. For a definition of federal and multilevel systems, see Anderson (2008, pp. 1-6).

2 In this book, we refer to the government with national powers as either "federal" or "central" government, recognizing that, in some federations, this order of government has a different title, such as "Union government" (in India), "central government" (in Spain), or "Commonwealth government" (in Australia). By "constituent units," we refer to the federal entities that make up the federation, such as provinces (Canada), states (Brazil, India, USA), cantons (Switzerland), Länder (Austria and Germany), or Autonomous Communities (Spain). See Anderson (2008, p. 2).

3 "Orders" of government refers to all constitutionally recognized layers of government in a federation. The authors of this book sometimes also refer to "levels" of government.

4 In some federations, local government is also recognized as a (third) distinct order of government.

\section{Bibliography}

Anderson, G., 2008. Federalism: An Introduction. Toronto: Oxford University Press.

Brunner, J.H., Sigurdsson, F.S., Svennebye, L. and Täube, V., 2020. COVID-19: Excess Mortality in Select European Countries. Luxembourg: European Free Trade Association Statistical Office. Ferejohn, J., Eskridge, W. and Bednar, J., 2001. A Political Theory of Federalism. In: Ferejohn, J., Rakove, J. and Riley, J., eds. Constitutional and Democratic Rule. New York: Cambridge University Press, 5-8.

Forum of Federations, 2015. Emergency Management in Federal Countries. Ottawa: Forum of Federations. Available from: http://www.forumfed.org/publications/report-emergencymanagement-in-federal-countries/ [Accessed 8 April 2021].

Greer, S., Rozenblum, S., Wismar, M. and Jarman, H., 2020. How Have Federal Countries Organized Their Covid Response? COVID-19 Health System Monitor. World Health Organization, 16 July. Available from: https://analysis.covid19healthsystem.org/index. php/2020/07/16/how-have-federal-countries-organized-their-covid-19-response/ [Accessed 8 April 2021]. 
Hueglin, T.O. and Fenna, A., 2015. Comparative Federalism: A Systematic Enquiry. Toronto: University of Toronto Press.

Ionova, A., 2020. Brazil's First Wave Isn’t Over Yet. ForeignPolicy.com. Foreign Policy, 29 October. Available from: https://foreignpolicy.com/2020/10/29/brazils-first-wave-not-overyet-coronavirus-pandemic-manaus-bolsonaro/ [Accessed 8 April 2021].

Kontis, V., Bennett, J.E., Rashid, T., Parks, R.M., Pearson-Stuttard, J., Guillot, M., Asaria, P., Zhou, B., Battaglini, M., Corsetti, G., McKee, M., Di Cesare, M., Mathers, C.D. and Ezzati, M., 2020. Magnitude, Demographics and Dynamics of the Effect of the First Wave of the COVID-19 Pandemic on All-Cause Mortality in 21 Industrialized Countries. Nature Medicine, 26, 1919-1928. Available from: https://doi.org/10.1038/s41591-020-1112-0 [Accessed 8 April 2021].

Marchildon, G.P. and Bossert, T.J., 2018. Federalism and Decentralization in Health Care: A Decision Space Approach. Toronto: University of Toronto Press.

Oates, W.E., 1999. An Essay on Fiscal Federalism. Journal of Economic Literature, 37 (3), $1120-1149$.

OECD, 2020. The Territorial Impact of COVID-19: Managing the Crisis Across Levels of Government. Paris: Organisation for Economic Cooperation and Development.

Relman, D.A., Choffnes, E.R. and Mack, A., Rapporteurs, 2010. The Domestic and International Impacts of the 2009-H1N1 Influenza A Pandemic: Global Challenges, Global Solutions: Workshop Summary. Washington, DC: Institute of Medicine.

Ritchie, H., Ortiz-Ospina, E., Beltekian, D., Mathieu, E., Hasell, J., Macdonald, B., Giattino, C. and Roser, M., 2021. Coronavirus (COVID-19) Deaths. Oxford: Our World in Data. Available from: https://ourworldindata.org/covid-deaths [Accessed 8 April 2021].

World Health Organization, 2020. Report of the WHO-China Joint Mission on Coronavirus Disease 2019 (COVID-19). Geneva: World Health Organization.

World Health Organization Department of Communicable Disease Surveillance and Response, 2003. Consensus Document on the Epidemiology of Severe Acute Respiratory Syndrome (SARS). Geneva: World Health Organization.

Wu, J., Cai, W., Watkins, D. and Glanz, J. How the Virus Got Out [online]. The New York Times, 22 March. Available from: https://www.nytimes.com/interactive/2020/03/22/world/ coronavirus-spread.html [Accessed 8 April 2021]. 